Citation: Bolshakov, S, Kalinina, L. Palomozhnykh, E., Potapov, K., Ageyev, D. Arslanov, S., Filippova, N., Palamarchuk, M. Tomchin, D., and Voronina, E. 2021. Agaricoid and boletoid fungi of Russia: the modern country-scale checklist of scientific names based on literature data. Bio. Comm. 66(4): 316-325. https://doi. org/10.21638/spbu03.2021.404

Author's information: Sergey Bolshakov MSc, Junior Researcher, orcid.org/0000 0002-6208-7792; Lyudmila Kalinina, PhD, Researcher, orcid.org/0000-0002-78098891; Ekaterina Palomozhnykh, Leading Collection Manager, orcid org/0000-0002 0789-8365; Kim Potapov, Senior Lecturer, orcid.org/0000-0002-5103-1021; Dmitry Ageyev, Senior Technical Support Specialist, orcid.org/0000-0002-0485-1908; Salavat Arslanov, orcid.org/0000-0002-6327-7870; Nina Filippova, PhD, Senior Researcher, orcid.org/0000-0002-9506-0991; Marina Palamarchuk, PhD, Senior Researcher, orcid. org/0000-0001-8538-969X; Dmitry Tomchin PhD, Researcher, orcid.org/0000-00024223-373X; Elena Voronina, PhD, Associate Professor, orcid.org/0000-0002-5282-6723

Manuscript Editor: Tatiana Svetasheva, Lev Tolstoy Tula State Pedagogical University, Tula, Russia

Received: May 18, 2020;

Revised: July 17, 2021;

Accepted: October 18, 2021.

Copyright: (c) 2021 Bolshakov et al. This is an open-access article distributed under the terms of the License Agreement with Saint Petersburg State University, which permits to the authors unrestricted distribution, and self-archiving free of charge.

Funding: The work of Sergey Bolshakov, Lyudmila Kalinina, and Ekaterina

Palomozhnykh was supported by the institutional research project of the Komarov Botanical Institute ("Biodiversity, ecology, structural and functional

features of fungi and fungus-like protists", AAAA-A19-119020890079-6) and partly supported by the Russian Foundation for Basic Research, project No. 20-04-00349 A. The work of Nina Filippova was partly supported by the Grant for organisation of a new young researcher laboratory in Yugra State University, as part of the implementation of the National Project "Science and Universities". The work of Marina Palamarchuk was carried out within the framework of the institutional research project of the Institute of Biology of the Komi Science Centre, Ural Branch of the Russian Academy of Sciences (No. AAAA-A19-119011790022-1). The work of Elena Voronina was carried out as part of the Scientific Project of the State Order of the Government of Russian Federation to Lomonosov Moscow State University No. 121032300081-7.

Ethics statement: This paper does not contain any studies involving human participants or animals performed by any of the authors.

Supplementary information:

Supplemental material to the article is available at https://doi.org/10.21638/ spbu03.2021.404. Supplementary files are published as submitted by the authors, and are not copyedited.

Competing interests: The authors have declared that no competing interests exist.

\section{Agaricoid and boletoid fungi of Russia: the modern country-scale checklist of scientific names based on literature data}

\section{Sergey Bolshakov ${ }^{1}$, Lyudmila Kalinina1, Ekaterina Palomozhnykh¹, Kim Potapov², Dmitry Ageyev ${ }^{3}$, Salavat Arslanov4, Nina Filippova ${ }^{5}$, Marina Palamarchuk ${ }^{6}$, Dmitry Tomchin ${ }^{7}$, and Elena Voronina ${ }^{8}$}

${ }^{1}$ Laboratory of Systematics and Geography of Fungi, Komarov Botanical Institute, Russian Academy of Sciences, ul. Professora Popova, 2, Saint Petersburg, 197376, Russian Federation

${ }^{2}$ Department of General Ecology, Institute of Environmental Sciences, Kazan (Volga Region) Federal University, ul. Kremlyovskaya, 18, Kazan, 420008, Russian Federation

${ }^{3}$ Signatec Ltd., ul. Inzhenernaya, 22, Novosibirsk, 630090, Russian Federation ${ }^{4}$ Saint Petersburg Mycological Society, Izmailovsky Pr., 22-1, Saint Petersburg, 190005 Russian Federation

${ }^{5}$ Department of Environmental Dynamics and Global Climate Change, Yugra State University, ul. Chekhova, 16, Khanty-Mansiysk, 628012, Russian Federation

${ }^{6}$ Department of Flora and Vegetation of the North, Institute of Biology, Komi Science Centre, Ural Branch of the Russian Academy of Sciences, ul. Kommunisticheskaya,

28, Syktyvkar, 167982, Russian Federation

${ }^{7}$ Control of Complex Systems Laboratory, Institute for Problems in Mechanical Engineering, Russian Academy of Sciences, Bolshoy Pr. V. O., 61, Saint Petersburg, 199178,

Russian Federation

${ }^{8}$ Department of Mycology and Algology, Faculty of Biology,

Lomonosov Moscow State University, Leninskiye Gory, 1/12, Moscow, 119234,

Russian Federation

Address correspondence and requests for materials to Sergey Bolshakov, s.bolshakov.ru@gmail.com

\section{Abstract}

The authors of this paper summarize the majority of published data on the distribution of agaricoid and boletoid fungi recorded in Russia, covering the period from 1824 through 2020. A comprehensive list of 6867 scientific names based on 954 publications was compiled for the first time for the whole territory of Russia. All records have been checked through Index Fungorum. The work consists of a review section and five appendices. The review section discusses the intensity of field research and accumulation of data on the distribution of agaricoid and boletoid fungi in Russia, both historically and in its current state. The authors discuss the current state of knowledge on the biodiversity of regions of Russia and point out blank spots, thus providing a reference and an "action plan" for the future. Appendix A presents a list of 6142 taxa unambiguously ascribed to 3246 accepted current names. Appendix B contains 727 names that cannot be ascribed to any accepted current names unequivocally, with reasons given (e.g., no current name, wrong authors' citations, absence from Index Fungorum). Names from both checklists are supplemented with data on the distribution of these taxa within the Russian Federation and references to published records. Appendix C contains a list of accepted current names reported from only one region. Appendix $D$ is an overview of the nearly 200 years of research of agaricoid and boletoid fungi for all regions of Russia. Appendix $E$ is a list of references used for checklists and study history preparation.

Keywords: Agaricomycetes, funga, fungal biodiversity and distribution, review, Russian Federation

\section{Introduction}

This study aims to summarize published data on agaricoid and boletoid fungi (Basidiomycota, Agaricomycetes) recorded from the modern territory of Russia (including Crimea). To our knowledge, there is no up-to-date comprehensive 
summary of all, or at least the majority of the published data on this group of fungi, which is highly diverse and important, both ecologically and economically.

By "agaricoid and boletoid fungi", we mean basidiomycete macrofungi with fleshy pileate-stipitate basidiomata and gilled or tubular hymenophore ("agarics and boleti”) (Moser, 1978; Singer, 1986; Knudsen and Vesterholt, 2008, 2012; Halbwachs, Simmel and Bässler, 2016; Sánchez-García et al., 2020). Phylogenetically related cyphelloid, secotioid or gasteroid species as well as groups traditionally treated as "aphyllophoroid" (clavarioid, corticioid, polyporoid, etc.) were omitted. According to modern taxonomical concepts, taxa of this group belong to the Agaricales, Boletales, Gloeophyllales, Hymenochaetales, Polyporales, and Russulales (all orders pro parte) (He et al., 2019).

At the moment, literature containing data on the diversity and distribution of "agarics and boleti" in Russia is burdened with too many redundant names for the same organisms. We took on the task of compiling the essential data from numerous, scattered and sometimes hardly available scientific papers focused mostly on agaricoid and boletoid fungi diversity, taxonomy, and ecology (see "Data source" section) and arranging them into a literature-based all-Russian checklist of scientific names of agaricoid and boletoid fungi. The information included makes it possible to: 1) estimate the general number of agaricoid and boletoid names registered from the territory for every Russian administrative region and the Federation as a whole; 2) estimate spatial study coverage and subsequently reveal blank spots (unstudied or poorly studied regions); 3 ) provide researchers in the fields of mycogeography and fungal taxonomy with information on species distribution through the checklist as well as the full references list.

The presented study was planned as a "panoramic view" of the known agaricoid and boletoid fungi of Russia. We did not aim to assess the true diversity of this group, and thus limited our effort to revealing gaps in the existing knowledge, which would be of use in planning further inventorying studies of this group of fungi.

\section{Data Gathering \& Processing}

Data sources. The data for the assessment were extracted from scientific publications and $\mathrm{PhD}$ theses containing information on the distribution of agaricoid and boletoid fungi in Russia. To choose relevant and appropriate publications, we took the following steps: 1) examination of archives of the Russian mycological journal "Mycology and Phytopathology (Mikologiya i fitopatologiya)" and "Novitates Systematicae Plantarum non Vascularium (Novosti sistematiki nizshikh rastenii)"; 2) analysis of Russian experts' profiles in the Russian Science Citation Index bibliography database as well as bibliographies of classic mycologists (Weinmann, Thümen, Karsten, Singer, etc.); 3) analysis of reference lists in the publications selected on the previous two steps. Also, references were obtained from historical overviews of regional botanical and mycological research as well as from search queries via Google Scholar, Scopus, and Web of Science.

The publications used to compile the checklist were obtained from the library of Komarov Botanical Institute of the Russian Academy of Sciences as well as from online and private libraries.

We collected and scrutinized 954 scientific works dating from 1824 to 2020 (journal articles, monographs, book sections, conference proceedings, and $\mathrm{PhD}$ theses) of the following types: 1 ) inventorying studies with species lists for specific territories; 2) taxonomic revisions with data on the examined specimens and their localities; 3) ecological research with information on area of study locality and fungal species arranged in tables or listed in the text as a background for the main research objects. Unpublished data presented in nature reserve annals and research reports were not included. We did not include data from field guides intended for the broad public.

While there remains a possibility of some small gaps in the coverage of this publication, the multifaceted data mining approach has ensured that the vast majority of literature sources on the Russian agaricoid and boletoid fungi has been incorporated in the checklist.

Data processing. The primary data for the agaricoid and boletoid scientific names checklist was recorded to a flat database in Google Sheets. It contains three main tables - data on species distribution, references and nomenclator, interlinked by data validation, functions, and queries by Google Visualization API Query Language (Bolshakov et al., 2017). Each database line contains basic information on the taxon name: its scientific name with authors' citation, first-level administrative region of Russia and the reference from which the record was obtained. To avoid inaccuracy of the database content, data validation was applied to the species included. Various misprints and errors in the authors' citations of scientific names were corrected when entered in the database in accordance with the correct name in Index Fungorum (IF).

IF was used for classification of scientific names applied to taxa of specific and infraspecific ranks (current names and their homotypic and heterotypic synonyms). The queries to IF were performed on 18.05.2021 through the API using package "taxize" 0.9.99 for R 4.0.5 (Chamberlain and Szöcs, 2013; Chamberlain et al., 2020). Nomenclature for the Bolbitiaceae family follows E. F. Malysheva's monograph (2018).

Geographic scope. For the assessment, only those records were selected that could be unambiguously ascribed to any of 85 first-level administrative regions of Russia, including Crimea (as they are defined by the Constitution (Chapter 65 and the corresponding Federal 
Law from March 21, 2014)). Records from the territories that were part of Russian territory in the past, but not at present, were not considered.

In order to avoid the probable misinterpretation of Russian territory administrative division, the geography of records is presented as transliteration of correspondent territorial subjects' ranks instead of its formal English translation (e.g., Krai instead of Territory, Oblast instead of Region, etc.).

As a result of state reforms in 1990-1993, a number of Russian administrative regions changed their ranks or borders. Thus, the Altai Republic was established within the Altai Krai, and the Republic of Khakassia within the Krasnoyarsk Krai; later, the two Republics became independent federal subjects. The cities of Moscow and St. Petersburg became independent federal subjects within their regions (Moscow Oblast and Leningrad Oblast, respectively); the Khanty-Mansi Autonomous Okrug and YamaloNenets Autonomous Okrug (formerly parts of the Tyumen Oblast) obtained the rank of federal subjects, etc. The corresponding corrections were applied to records that had exact localities provided, making it possible to apply the current territorial nomenclature. If, for instance, the original record was made in the then-Altai Krai, with the precise locality in the Altaiskiy Nature Reserve (now located in the Altai Republic), in the database, it was ascribed to the Altai Republic. In cases when it was impossible to define the exact record localities, as in the case of the Leningrad Oblast checklist (Popov et al., 2007) based on data from Kovalenko and Morozova (1999) and containing records both for Leningrad Oblast and Saint Petersburg (authors' pers. comm.), the broader region (Leningrad Oblast) was specified. The Voronezhskiy Biosphere Reserve lies in the territories of both Lipetsk and Voronezh Oblasts. Records without exact localities were mentioned for both regions.

Bearing in mind the vastness of Russia, we divided its territory into three longitudinal sectors for ease of analysis - Eastern Europe (including the Northern Caucasus and Urals), Siberia, and the Far East. To avoid dividing the Ural Mountains, the boundary between Europe and Siberia and a region of high biodiversity, we are treating it as delimited not by administrative boundaries, but rather by the eastern foothills of the Ural Mountains (200 m. a.s.l.).

\section{Study History}

The research history of agarics and boleti in Russia can be tentatively divided into four periods (preliminary, early, classical, and modern). During the preliminary period, research was focused mainly on economically important fungi. In publications from the early period, scattered information on fungi can be found predominantly in reports on academic expeditions organized by the Academy of Sciences, which was established in 1724 (Vassilkov, 1953).
The classical period began with Johann A. Weinmann, the first Russian botanist to contribute significantly to mycological studies in the country. He summarized all existing data on macromycetes of the Russian Empire (Weinmann, 1836). Later, only scattered data on agaricoid and boletoid fungi appeared in works of both Russian (Arthur A. Jaczewski, Fedor V.Bucholtz, etc.) and foreign (Felix von Thümen, Pier A. Saccardo, Petter A. Karsten, etc.) mycologists. The modern period began in the 1920 s, when pileate fungi became an independent object of study (Vassilkov, 1953). Lidia A.Lebedeva, Rolf Singer, Ljubov N. Vassileva and Boris P. Vassilkov were the first experts to focus on the study of agaricoid fungi in the USSR. Critically important research on the role of fungi in ecosystems was performed by Vladimir Ya. Chastukhin and colleagues (Chastukhin and Nikolaevskaya, 1969). The period between 1960 and 2000 was marked by the emergence of a number of regional centers of mycological research; beginning from 1990, the number of publications on agaricoid fungi increased dramatically. For detailed information on the published data (papers, researchers, regions etc.), see Appendix D.

Until the 1960s, no more than three publications a year contained any kind of contributions to the knowledge on agaricoid fungi, with rare exceptions; in the course of the following 40 years, until the 2000s, the number of such works published annually increased to $5-8$, and beginning from the 2000s, there were usually at least 20 papers published every year (Fig. 1A). The observed curve (Fig. 1C) of the number of publications not only proves the growing interest in various aspects of the biology and taxonomy of agaricoid fungi, but also reflects the explosive growth of publications, which can be considered a general trend in science since the 2000s (Fortunato et al., 2018).

By 1850 , the number of published accepted names reached 414 (Fig. 1C). Until the 1970s, data on agaricoid fungi diversity were accumulating very slowly: in the course of 100 years, the number of annually published accepted current names rarely exceeded 100 (Fig. 1B). By 1900, only 541 accepted current names had been published; by 1950 , this number increased to 1054. In 1920, Arthur Thesleff (1920) published 445 names for the territory of the modern Leningrad Oblast; in 1939, Vassiljeva (1939) mentioned 318 names for the Caucasus Nature Reserve (territory of modern Krasnodar Krai, Karachay-Cherkess Republic and Adygea); in 1949, Maria V. Freindling reported 228 names from the Kivach Nature Reserve (Karelia). Between 19702000 , the numbers of annually published accepted current names of agaricoid fungi varied between 100-900. The majority of large lists during this period were published by Matilda I. Beglyanova (1972) for Krasnoyarsk Krai and Khakassia - 677; Ljubov N. Vassiljeva (1973) for Primorsky Krai - 737; and Alexander E. Kovalenko and Olga V.Morozova (1999) for Leningrad Oblast and Saint Petersburg -872 accepted current names. It is noteworthy that beginning from 1962, data were published every year. By 

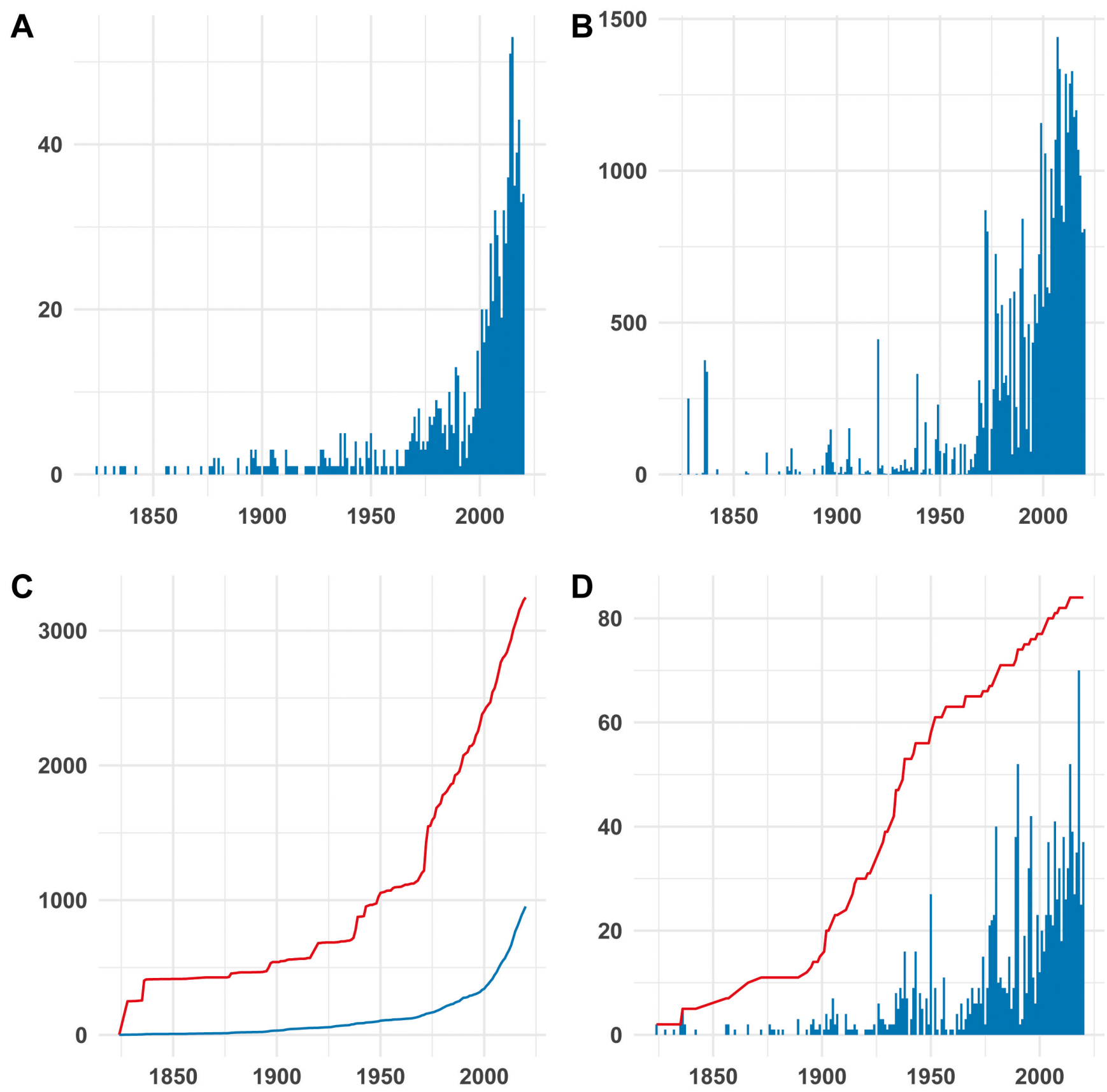

Fig. 1. Timelines of the agaricoid and boletoid fungi diversity research in Russia. A - Annually issued publications. B - Annually reported accepted current names. C - Accumulated numbers of publications (blue line) and detected accepted current names (red line). D - Numbers of studied regions, per year (blue columns) and accumulated (red line).

2000, 2402 accepted current names were published. Since the 2000s, the number of annually published accepted current names increased to $500-1400$.

In the $19^{\text {th }}$ century, the number of studied regions increased insignificantly; by 1900, data on agaricoid and boletoid fungi existed only for 15 regions (Fig. 1D). By 1950 , the number increased to 58 , and by $2000-$ to 77 . It should be noted that here, we do not assess the intensity of agaricoid fungi research, but simply state the fact of even a single accepted name mentioned for a particular region.

\section{Geographic Distribution}

We compiled a list of 6867 names published in 954 scientific papers for 84 of 85 currently existing administrative regions. No data on the Republic of Ingushetia were found. Every name was checked for its current name in IF.

After checking the list against the IF database, all names found in published sources were divided into four groups: 1) 6142 names ascribed unambiguously to accepted current names (as given in IF); 2) 468 names 
Table 1. Density of agaricoid and boletoid fungi research in Russia administrative regions

\begin{tabular}{|c|c|c|c|c|c|}
\hline Administrative regions & Code & $\begin{array}{c}\text { Accepted } \\
\text { current names }\end{array}$ & $\begin{array}{c}\% \text { total accepted } \\
\text { names }\end{array}$ & $\begin{array}{l}\text { “Unique" } \\
\text { names }\end{array}$ & $\begin{array}{c}\text { Number of } \\
\text { publications }\end{array}$ \\
\hline Adygea & $A D$ & 441 & 13.58 & 20 & 26 \\
\hline Altai Krai & ALT & 473 & 14.57 & 4 & 17 \\
\hline Altai Republic & $\mathrm{AL}$ & 798 & 24.58 & 60 & 69 \\
\hline Amur Oblast & $\mathrm{AMU}$ & 466 & 14.35 & 3 & 39 \\
\hline Arkhangelsk Oblast & ARK & 137 & 4.22 & 2 & 20 \\
\hline Astrakhan Oblast & AST & 37 & 1.14 & 2 & 5 \\
\hline Bashkortostan & BA & 70 & 2.16 & 2 & 11 \\
\hline Belgorod Oblast & BEL & 431 & 13.27 & 6 & 22 \\
\hline Bryansk Oblast & BRY & 206 & 6.34 & 0 & 8 \\
\hline Buryatia & BU & 399 & 12.29 & 10 & 40 \\
\hline Chechen Republic & CE & 97 & 2.99 & 0 & 6 \\
\hline Chelyabinsk Oblast & $\mathrm{CHE}$ & 241 & 7.42 & 4 & 12 \\
\hline Chukotka Autonomous Okrug & $\mathrm{CHU}$ & 271 & 8.35 & 4 & 25 \\
\hline Chuvash Republic & $\mathrm{CU}$ & 49 & 1.51 & 0 & 5 \\
\hline Crimea & KM & 655 & 20.17 & 20 & 33 \\
\hline Dagestan & DA & 7 & 0.22 & 0 & 5 \\
\hline Ingushetia & IN & 0 & 0 & 0 & 0 \\
\hline Irkutsk Oblast & IRK & 787 & 24.24 & 11 & 60 \\
\hline Ivanovo Oblast & IVA & 21 & 0.65 & 0 & 6 \\
\hline Jewish Autonomous Oblast & YEV & 452 & 13.92 & 3 & 15 \\
\hline Kabardino-Balkarian Republic & KB & 284 & 8.75 & 6 & 12 \\
\hline Kaliningrad Oblast & KGD & 670 & 20.63 & 13 & 12 \\
\hline Kalmykia & $\mathrm{KL}$ & 3 & 0.09 & 0 & 2 \\
\hline Kaluga Oblast & KLU & 302 & 9.3 & 0 & 10 \\
\hline Kamchatka Krai & KAM & 201 & 6.19 & 4 & 26 \\
\hline Karachay-Cherkess Republic & KC & 372 & 11.46 & 8 & 23 \\
\hline Karelia & $\mathrm{KR}$ & 781 & 24.05 & 22 & 51 \\
\hline Kemerovo Oblast & KEM & 45 & 1.39 & 0 & 7 \\
\hline Khabarovsk Krai & $\mathrm{KHA}$ & 683 & 21.03 & 15 & 43 \\
\hline Khakassia & KK & 437 & 13.46 & 13 & 12 \\
\hline Khanty-Mansi Autonomous Okrug & KHM & 671 & 20.67 & 36 & 27 \\
\hline Kirov Oblast & $\mathrm{KIR}$ & 329 & 10.13 & 0 & 16 \\
\hline Komi Republic & $\mathrm{KO}$ & 720 & 22.17 & 22 & 36 \\
\hline Kostroma Oblast & KOS & 67 & 2.06 & 0 & 3 \\
\hline Krasnodar Krai & $\mathrm{KDA}$ & 609 & 18.76 & 32 & 48 \\
\hline Krasnoyarsk Krai & KYA & 1158 & 35.66 & 47 & 99 \\
\hline Kurgan Oblast & KGN & 92 & 2.83 & 0 & 6 \\
\hline Kursk Oblast & KRS & 175 & 5.39 & 0 & 15 \\
\hline Leningrad Oblast & LEN & 1193 & 36.74 & 35 & 88 \\
\hline Lipetsk Oblast & LIP & 518 & 15.95 & 4 & 15 \\
\hline Magadan Oblast & MAG & 487 & 15 & 8 & 29 \\
\hline Mari El Republic & ME & 72 & 2.22 & 0 & 9 \\
\hline
\end{tabular}




\begin{tabular}{|c|c|c|c|c|c|}
\hline Administrative regions & Code & $\begin{array}{c}\text { Accepted } \\
\text { current names }\end{array}$ & $\begin{array}{c}\% \text { total accepted } \\
\text { names }\end{array}$ & $\begin{array}{l}\text { “Unique" } \\
\text { names }\end{array}$ & $\begin{array}{l}\text { Number of } \\
\text { publications }\end{array}$ \\
\hline Mordovia & MO & 283 & 8.72 & 4 & 35 \\
\hline Moscow & MOW & 240 & 7.39 & 8 & 19 \\
\hline Moscow Oblast & MOS & 836 & 25.75 & 21 & 46 \\
\hline Murmansk Oblast & MUR & 451 & 13.89 & 12 & 52 \\
\hline Nenets Autonomous Okrug & NEN & 16 & 0.49 & 1 & 4 \\
\hline Nizhny Novgorod Oblast & NIZ & 28 & 0.86 & 0 & 6 \\
\hline North Ossetia & SE & 135 & 4.16 & 1 & 4 \\
\hline Novgorod Oblast & NGR & 492 & 15.15 & 9 & 35 \\
\hline Novosibirsk Oblast & NVS & 649 & 19.99 & 10 & 30 \\
\hline Omsk Oblast & OMS & 16 & 0.49 & 0 & 6 \\
\hline Orenburg Oblast & ORE & 322 & 9.92 & 8 & 15 \\
\hline Oryol Oblast & ORL & 72 & 2.22 & 1 & 6 \\
\hline Penza Oblast & PNZ & 744 & 22.91 & 25 & 36 \\
\hline Perm Krai & PER & 848 & 26.12 & 17 & 29 \\
\hline Primorsky Krai & PRI & 1313 & 40.44 & 166 & 92 \\
\hline Pskov Oblast & PSK & 590 & 18.17 & 7 & 21 \\
\hline Rostov Oblast & ROS & 419 & 12.9 & 12 & 18 \\
\hline Ryazan Oblast & RYA & 530 & 16.32 & 10 & 11 \\
\hline Saint Petersburg & SPE & 833 & 25.65 & 35 & 54 \\
\hline Sakha Republic & SA & 180 & 5.54 & 17 & 45 \\
\hline Sakhalin Oblast & SAK & 331 & 10.19 & 12 & 33 \\
\hline Samara Oblast & SAM & 496 & 15.28 & 16 & 35 \\
\hline Saratov Oblast & SAR & 99 & 3.05 & 1 & 11 \\
\hline Sevastopol & SEV & 210 & 6.47 & 3 & 5 \\
\hline Smolensk Oblast & SMO & 173 & 5.33 & 1 & 8 \\
\hline Stavropol Krai & STA & 45 & 1.39 & 3 & 20 \\
\hline Sverdlovsk Oblast & SVE & 762 & 23.47 & 12 & 27 \\
\hline Tambov Oblast & TAM & 15 & 0.46 & 0 & 2 \\
\hline Tatarstan & TA & 564 & 17.37 & 12 & 36 \\
\hline Tomsk Oblast & TOM & 783 & 24.11 & 24 & 38 \\
\hline Tula Oblast & TUL & 686 & 21.13 & 10 & 25 \\
\hline Tver Oblast & TVE & 429 & 13.21 & 5 & 29 \\
\hline Tyumen Oblast & TYU & 51 & 1.57 & 2 & 11 \\
\hline Tyva Republic & TY & 42 & 1.29 & 1 & 3 \\
\hline Udmurt Republic & UD & 481 & 14.81 & 3 & 6 \\
\hline Ulyanovsk Oblast & ULY & 349 & 10.75 & 1 & 9 \\
\hline Vladimir Oblast & VLA & 42 & 1.29 & 0 & 8 \\
\hline Volgograd Oblast & VGG & 172 & 5.3 & 16 & 19 \\
\hline Vologda Oblast & VLG & 461 & 14.2 & 6 & 26 \\
\hline Voronezh Oblast & VOR & 322 & 9.92 & 1 & 18 \\
\hline Yamalo-Nenets Autonomous Okrug & YAN & 317 & 9.76 & 7 & 32 \\
\hline Yaroslavl Oblast & YAR & 412 & 12.69 & 2 & 12 \\
\hline Zabaykalsky Krai & $\mathrm{ZAB}$ & 53 & 1.63 & 0 & 5 \\
\hline
\end{tabular}




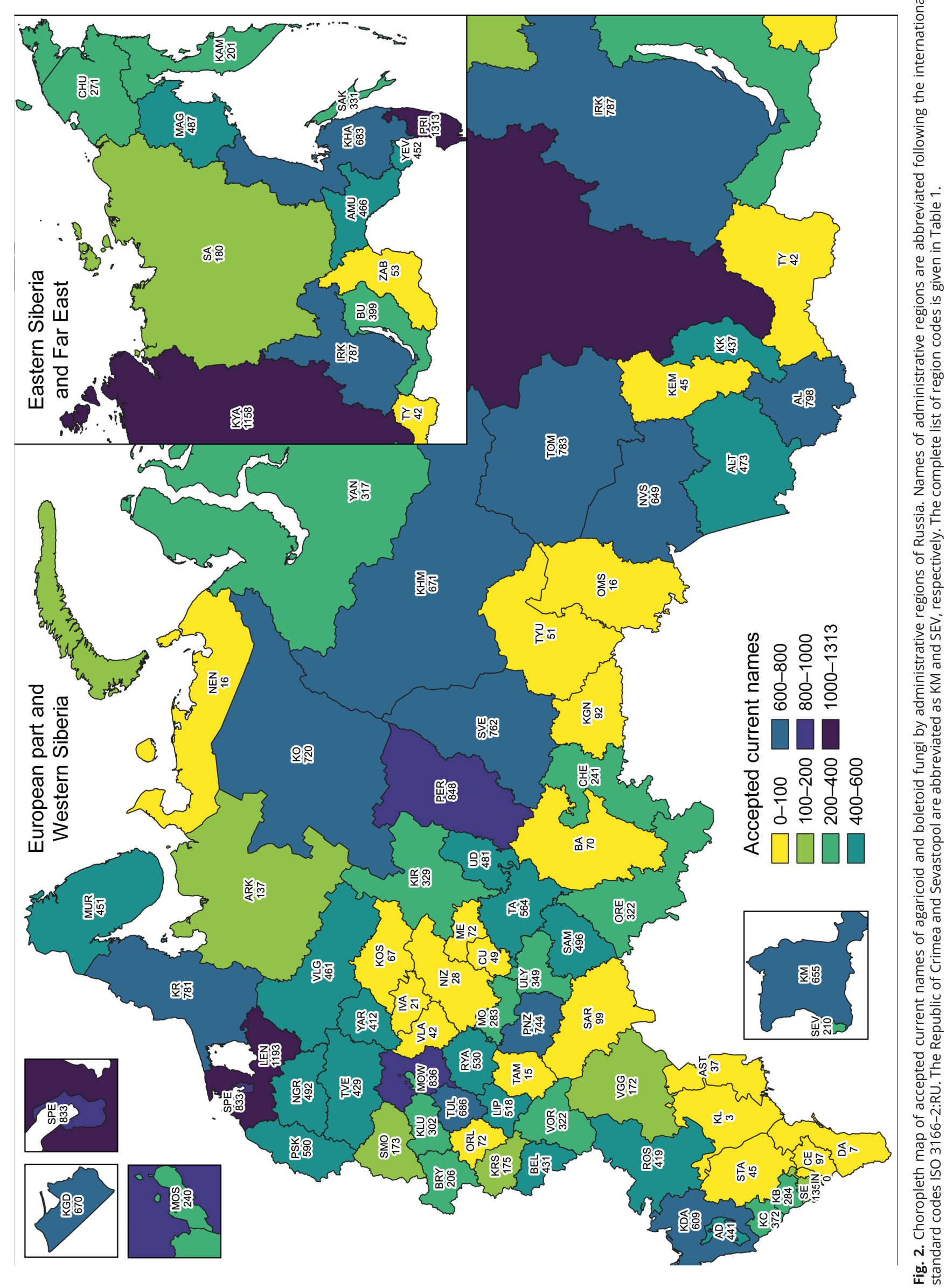




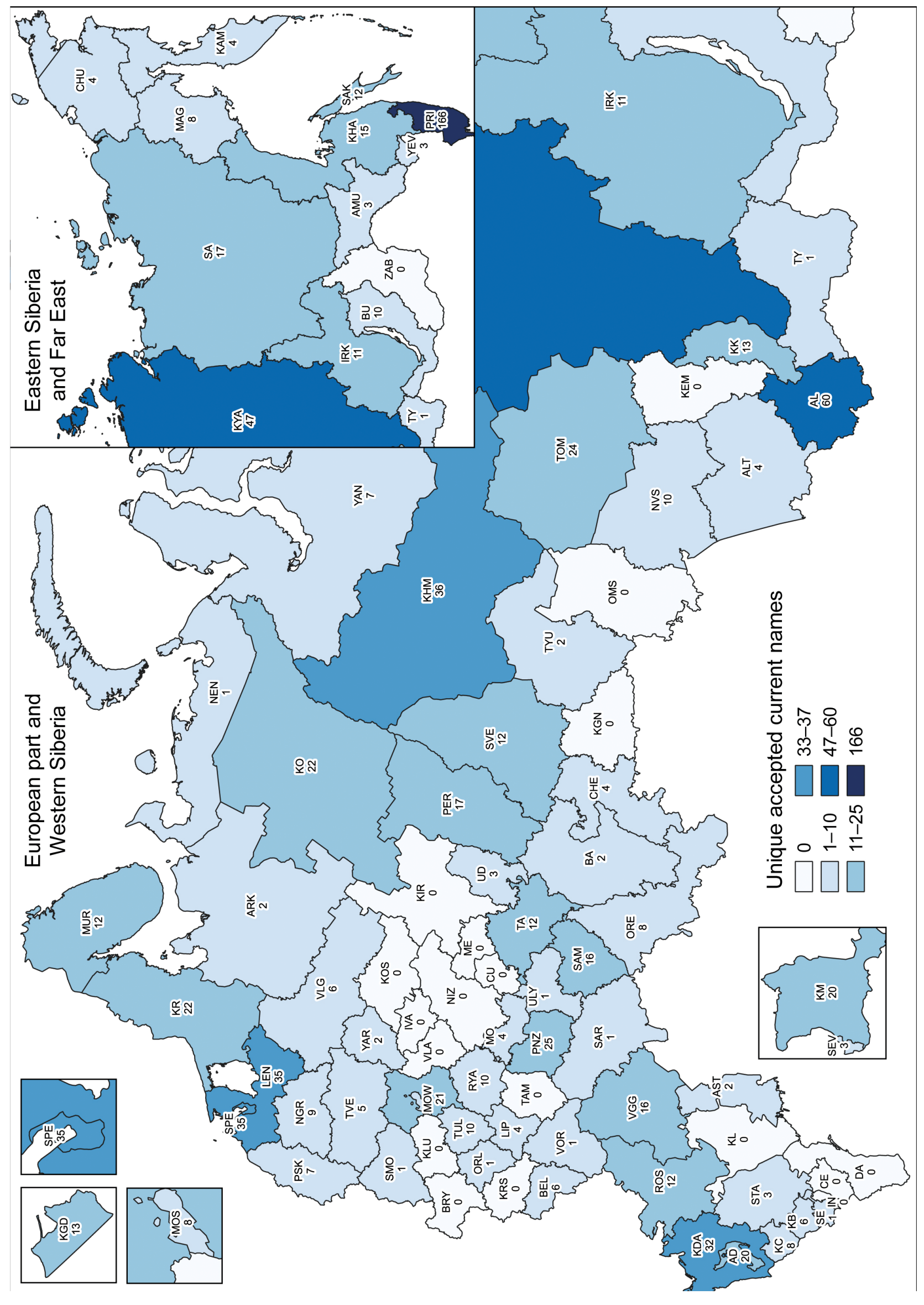

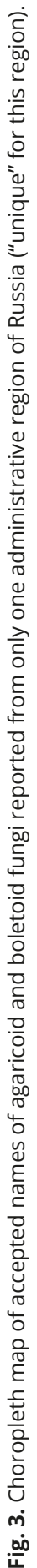


that have no current name; 3) 72 correct binomials with incorrect author citations, i.e., such that do not match any records in IF; 4) 187 genus-species or infraspecific combinations absent from IF.

Names unambiguously interpreted according to IF are included in the first list. Infraspecific autonyms without current names also belong here. Such names are given in Appendix A as a list of current names with synonyms.

The second list given in Appendix B enumerates taxa with missing current names as well as correct binomials with wrong author citations. It is impossible to interpret them unambiguously and to bring into correlation with certain current names. Names absent from IF are also included in the second list.

The compiled list of fungal names cannot represent the real structure of the mycobiota, because it contains scientific names of different levels of reliability. Therefore, it can only be subjected to very basic analysis. For the following summary and analyses, we only used information on names and regions from the first list (Appendix A). We consider the authors of the original papers to be in charge of the accuracy of reported species identification.

By 2020, a total of 3246 accepted current names of agaricoid and boletoid fungi were reported for Russia. The general statistics for regions is presented in Table 1 . A choropleth map of research density is shown in Fig. 2. The numbers of accepted names recorded for each region differ dramatically. 918 accepted scientific names are known from only one region, 1381 are reported from 2-10 regions, 847 - from 11-50 regions. Only 85 species are reported from more than 50 regions. 15 accepted current names were published as occurring in Russia without the exact region of collection.

The most thoroughly studied regions (more than 1000 accepted names of agaricoid and boletoid fungi reported) are Primorsky Krai - 1313, Leningrad Oblast -1193 , Krasnoyarsk Krai -1158 . The number of well-studied regions (500-1000 names reported) is 21 , and there are lists of 100-500 names for 38 regions. The median for all regions is 340 .

At the same time, there are three regions with less than 10 accepted names known: Ingushetia -0 , Kalmykia - 3, Dagestan - 7. There are 23 understudied regions in Russia with less than 100 accepted names published. In most cases, there are no published studies of agaricoid and boletoid fungi in these territories, and data for the checklist were obtained from Soviet floras and regional Red lists.

The distribution of 919 currently accepted names known only from a single region also substantially differs from region to region. The following territories are the richest in such "unique" taxa: Primorsky Krai - 166, Altai Republic - 60, Krasnoyarsk Krai - 47, KhantyMansi Autonomous Okrug - 36, Leningrad Oblast 35, Saint Petersburg - 35, Krasnodar Krai - 32.

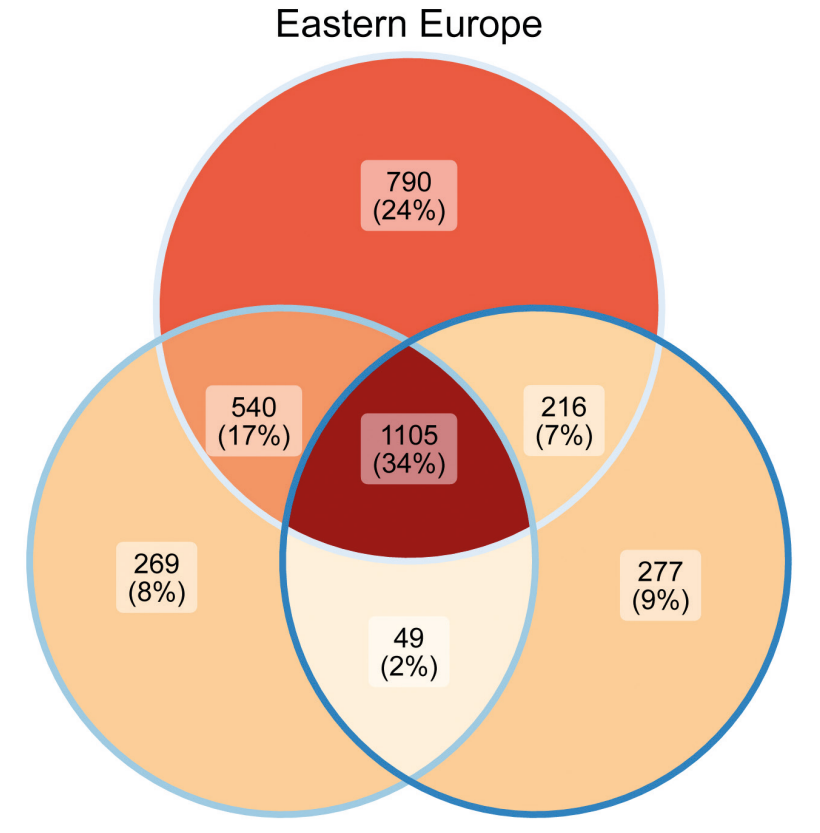

Siberia

Far East

Fig. 4. Comparison of lists of accepted current names for longitudinal sectors.

At least 30 such names are recorded in 59 regions, while in 19 regions, there are no unique finds (Fig. 3, Table 1). The full lists of such names for each region are given in Appendix $\mathrm{C}$ arranged by longitudinal sectors.

The lists of accepted current names have been compared by longitudinal sectors. In the Eastern European part of Russia 2629 names are recorded, in Siberia - 1959, in the Russian Far East - 1647. A total of 1105 accepted current names are shared by the three sectors. A total of 790 names are unique for the Eastern European Sector, 269 for Siberia and 277 for the Far East (Fig. 4).

The distribution of "unique" accepted names between sectors is as follows: 468 in Eastern Europe, 235 in Siberia and 215 in the Far East (Appendix C).

\section{Concluding remarks}

We thoroughly checked all available libraries to find as many publications dealing with agaricoid fungi of Russia as possible. We found 954 works by hundreds of authors in five languages dating from 1824 to 2020 in order to compile the most comprehensive bibliography to date and summarize the existing data, bringing it to the "common denominator" by updating the nomenclature (the accumulated bulk of taxonomical changes gravely complicates the use of these data in their original form); at the same time, the checklist also contains all original information, including synonyms, ambiguous names, etc. The resulting checklist clearly demonstrates that despite more than 150 years of agaricoid fungi research in Russia, there are regions that are in desperate need 
of inventorying studies, revealing unexpectedly massive blank spots on the "agaricological" map of Russia. There have been no surveys whatsoever in over twenty regions (Fig. 2); while Northern Caucasus, South Siberia and the Far East are in need of more detailed surveying. We hope that our work will inspire scientists to invest more effort into inventorying surveys, which are a cornerstone in biodiversity and biogeography research.

\section{Acknowledgements}

The work is dedicated to Prof. Alexander E. Kovalenko who passed away in December 2021. His hard and fruitful labour was instrumental in the advances of Russian mycological research. This project was initiated with his blessing. We are cordially grateful to our colleagues Olga S. Shiryaeva (Institute of Plant and Animal Ecology, Ural Branch of the Russian Academy of Sciences) and Eugene S. Popov (Komarov Botanical Institute of the Russian Academy of Sciences) for their helpful assistance in compiling data and valuable discussion and suggestions, to the Manuscript Editor Tatiana Yu. Svetasheva (Lev Tolstoy Tula State Pedagogical University) as well as the reviewers Henning Knudsen (Professor Emeritus of the Natural History Museum of Denmark, University of Copenhagen) and Slavomír Adamčík (Institute of Botany, Plant Science and Biodiversity Center, Slovak Academy of Sciences) for their valuable remarks and suggestions that greatly improved the quality of this publication. Also, we would like to thank Tatiana M. Bulyonkova (A. P. Ershov Institute of Informatics Systems, Siberian Branch of the Russian Academy of Sciences) for improving the quality of the English text, and for her comments on the subject of the study.

\section{References}

Beglyanova, M. I. 1972. Flora of agaricoid fungi of the southern part of the Krasnoyarsk Krai. Part I. Krasnoyarsk. (In Russian)

Bolshakov, S. Yu., Filippova, N. V., Potapov, K. O., Ageev, D. V., and Volobuev, S. V. 2017. Google Spreadsheets as a basic tool for the management of biodiversity data; pp. 21-23 in International Conference "The use of modern information technologies in botanical investigations" Apatity, Murmansk Province, March 28-31, 2017. Abstracts. Apatity. (In Russian)

Chamberlain, S.A. and Szöcs, E. 2013. taxize: taxonomic search and retrieval in R. F1000Research 2:191. https:// doi.org/10.12688/f1000research.2-191.v2

Chamberlain, S., Szoecs, E., Foster, Z., Arendsee, Z., Boettiger, C., Ram, K., Bartomeus, I., Baumgartner, J., O'Donnell, J., Oksanen, J., Tzovaras, B. G., Marchand, P., Tran, V., Salmon, M., Li, G., and Grenié, M. 2020. taxize: Taxonomic information from around the web. $\mathrm{R}$ package version 0.9.99, https://github.com/ropensci/taxize

Chastukhin, V. Ya. and Nikolaevskaya, M. A. 1969. Biodegradation and resynthesis of organic matter in nature. Nauka Publ., Leningrad. (In Russian)

Fortunato, S., Bergstrom, C.T., Börner, K., Evans, J.A., Helbing, D., Milojević, S., Petersen, A. M., Radicchi, F., Sinatra, R., Uzzi, B., Vespignani, A., Waltman, L., Wang, D., and Barabási, A.-L. 2018. Science of science. Science 359(6379). https://doi.org/10.1126/science.aao0185

Halbwachs, H., Simmel, J., and Bässler, C. 2016. Tales and mysteries of fungal fruiting: How morphological and physiological traits affect a pileate lifestyle. Fungal Bio- logy Reviews 30(2):36-61. https://doi.org/10.1016/j. fbr.2016.04.002

He, M.-Q., Zhao, R.-L., Hyde, K. D., Begerow, D., Kemler, M., Yurkov, A., McKenzie, E. H. C., Raspé, O., Kakishima, M., Sánchez-Ramírez, S., Vellinga, E. C., Halling, R., Papp, V., Zmitrovich, I. V., Buyck, B., Ertz, D., Wijayawardene, N. N., Cui, B.-K., Schoutteten, N., Liu, X.-Z., Li, T.-H., Yao, Y.-J., Zhu, X.-Y., Liu, A.-Q., Li, G.-J., Zhang, M.-Z., Ling, Z.-L., Cao, B., Antonín, V., Boekhout, T., da Silva, B. D. B., De Crop, E., Decock, C., Dima, B., Dutta, A. K., Fell, J.W., Geml, J., Ghobad-Nejhad, M., Giachini, A.J., Gibertoni, T.B., Gorjón, S. P., Haelewaters, D., He, S.-H., Hodkinson, B. P., Horak, E., Hoshino, T., Justo, A., Lim, Y. W., Menolli, N., Mešić, A., Moncalvo, J.-M., Mueller, G. M., Nagy, L. G., Nilsson, R. H., Noordeloos, M., Nuytinck, J., Orihara, T., Ratchadawan, C., Rajchenberg, M., SilvaFilho, A. G.S., Sulzbacher, M. A., Tkalčec, Z., Valenzuela, R., Verbeken, A., Vizzini, A., Wartchow, F., Wei, T.-Z., Weiß, M., Zhao, C.-L., and Kirk, P. M. 2019. Notes, outline and divergence times of Basidiomycota. Fungal Diversity 99(1):105-367. https://doi.org/10.1007/s13225-01900435-4

Knudsen, H. and Vesterholt, J. 2008. Funga Nordica. Agaricoid, boletoid and cyphelloid genera. 965 pp. Nordsvamp, Copenhagen.

Knudsen, H. and Vesterholt, J. 2012. Funga Nordica. Agaricoid, boletoid, clavarioid, cyphelloid and gastroid genera. 1083 pp. Nordsvamp, Copenhagen.

Kovalenko, A. E. and Morozova, O. V. 1999. Agaricoid and gasteroid macromycetes of the Leningrad Region; pp. 89140 in Balashova, N. B. and Zavarzin, A. A. (eds), Biodiversity of the Leningrad Region (Algae. Fungi. Lichens. Bryophytes. Invertebrates. Fishes and Pisciformis). St. Petersburg, St. Petersburg University Press. (In Russian)

Malysheva, E. F. 2018. Definitorium Fungorum Rossiae. Ordo Agaricales. Fasc. 2. Familia Bolbitiaceae. Nestor-Historia, St. Petersburg. (In Russian)

Moser, M. 1978. Kleine Kryptogamenflora. Band II: Pilze. Teil b: Basidiomyceten. Teil 2: Die Röhrlinge und Blätterpilze. 4. Stuttgart: G. Fischer.

Popov, E. S., Morozova, O. V., Kotkova, V. M., Novozhilov, Y. K., Zhurbenko, M. P., Zmitrovich, I. V., and Kovalenko, A. E. 2007. Preliminary list of fungi and myxomycetes of Leningrad Region. TREEART LLC, St. Petersburg.

Sánchez-García, M., Ryberg, M., Khan, F. K., Varga, T., Nagy, L. G., and Hibbett, D. S. 2020. Fruiting body form, not nutritional mode, is the major driver of diversification in mushroom-forming fungi. Proceedings of the $\mathrm{Na}$ tional Academy of Sciences USA 117(51):32528-32534. https://doi.org/10.1073/pnas.1922539117

Singer, R. 1986. The Agaricales in modern taxonomy. $4^{\text {th }}$ fully rev. ed. Koenigstein, Koeltz Scientific Books.

Thesleff, A. 1920. Studier öfver basidsvampfloran i sydöstra Finland med hänsyn till dess sammansättning, fysiognomi, fenologi och ekologi. Bidrag till Kännedom av Finlands Natur och Folk 79(1):1-140. (In Swedish)

Vassiljeva, L. N. 1939. Les champignons de la réserve Caucasienne. Scientific Notes of Kazan State University named after V. I. Ulyanov-Lenin 99(1):1-66. (In Russian)

Vassiljeva, L. N. 1973. Die Blätterpilze und Röhrlinge (Agaricales) von Primorsky Region. Nauka Publ., Leningrad. (In Russian)

Vassilkov, B.P. 1953. Pileate fungi study in the USSR. Edited by Savicz, V.P. Izdatel'stvo akademii nauk SSSR Publ., Moscow; Leningrad. (In Russian)

Weinmann, J. A. 1836. Hymeno- et Gastero-Mycetes hucusque in imperio Rossico observatos. Petropoli. (In Latin) 